\title{
PENERAPAN STRATEGI PRAMENULIS CUBING UNTUK MENINGKATKAN KEMAMPUAN MENULIS ARGUMENTASI DI SMP
}

\author{
Setyawan Pujiono \\ FBS Universitas Negeri Yogyakarta \\ E-mail: setya_one14@yahoo.com
}

\begin{abstract}
ABSTRAK
Penelitian tindakan kelas ini bertujuan untuk melakukan pembenahan terhadap kualitas pembelajaran keterampilan menulis argumentasi di sekolah. Pembenahan tersebut dapat dimulai dari pemilihan strategi pembelajaran yang tepat. Oleh karena itu, upaya tindakan ini akan mencoba meningkatkan kemampuan siswa pada pembelajaran keterampilan menulis argumentasi dengan strategi pramenulis cubing. Kegiatan penelitian ini dilaksanakan pada siswa kelas VIII SMP Negeri I Bambanglipuro Bantul Yogyakarta. Prosedur dalam penelitian ini adalah penelitian tindakan kelas (PTK). Untuk melaksanakan penelitian yang terarah dan teratur dalam prosesnya yang panjang dan kompleks, maka peneliti membagi pelaksanaan penelitian ini dalam siklus dan dilanjutkan dengan pengamatan, refleksi dan pelaporan. Hasil penelitian yang diperoleh bahwa strategi pramenulis cubing ternyata mampu meningkatkan kemampuam siswa dalam menulis argumentasi. Hasil pembahasan tim peneliti dalam proses pembelajaran dan produk tulisan siswa, ternyata strategi cubing dapat meningkatkan kemampuan menulis argumentasi. Hal tesebut dapat dilihat pada pemaparan argumentasi berikut ini. Subjek penelitian berjumlah 34 siswa, sedangkan dua siswa tidak mengikuti ujian akhir karena sakit. Hasil evaluasi siklus II (akhir) nilai yang diperoleh siswa antara 60 s.d 70 sejumlah 12 siswa, nilai 71 s.d 80 sejumlah 19 siswa, dan nilai yang di atas 81 sejumlah 1 siswa.
\end{abstract}

Keywords: prewriting, cubing, argumen, and strategi

\section{THE IMPLEMENTATION OF CUBING PRE-WRITING STRATEGY TO IMPROVE THE ABILITY TO WRITE ARGUMENTS IN JUNIOR HIGH SCHOOL}

\begin{abstract}
This class action research aim to do correction to quality of study of skill write argument in school. The correction can be started from election of correct study strategy. Therefore, this action effort will try to increase ability of student at study of skill write argument with strategy prewriting cubing. This research activity executed at class junior high school Bambanglipuro Bantul Yogyakarta. Procedure in this research is of class action research (CAR). To execute regular and directional research in process of his its complex and long, hence researcher divide execution of this research in cycle and continued with observation, reporting and reflection. Research result which obtained that strategy prewriting cubing simply can increase ability student in writing argument. Result solution of researcher team in process of student article product and study, simply strategy cubing can increase ability write argument. The increase ability write argument is visible at presentation following. Research subject amount to 34 student, while two student don't follow final exam because pain. Cycle evaluation result two (final) obtained by value is student between 60 up to 70 a number of 12 students, assess 71 up to 80 a number of 19 students, and above value 81 a number of 1 students.
\end{abstract}

\section{A. PENDAHULUAN}

Bahasa Indonesia menjadi salah satu mata pelajaran penting dan mempunyai pen- garuh besar terhadap kemampuan siswa dalam berkomuikasi. Melalui pembelajaran bahasa Indonesia, siswa dibekali dengan pengeta- 
huan formal bahasa, baik yang terkait dengan pengetahuan kaidah bahasa, proses berbahasa, maupun keterampilan berbahasa. Keterampilan berbahasa meliputi empat macam yaitu menyimak, berbicara, membaca dan menulis (Tarigan, 1994). Akan tetapi, yang menjadi kajian di sini adalah pada keterampilan menulis.

Menulis merupakan keterampilan berbahasa yang bertujuan untuk mengungkapkan ide, gagasan, serta perasaan secara tertulis (White, 1986). Dalam proses menulis siswa akan mengalami proses berpikir untuk mengungkapkan ide dan gagasannya secara luas (divergen thingking). Proses menulis sangat terkait hubungannya dengan faktor pengembangan berpikir, berdasarkan pengalaman yang mendasarinya. Dimana pengalaman tersebut dapat diperoleh melalui membaca, menyimak/pengamatan dan diskusi.

Tujuan dan manfaat pembelajaran tersebut di atas tidak secara bersamaan dapat dicapai, tetapi satu per satu mana yang menjadi prioritas dan tujuan yang ingin dicapai. Oleh karena itu, pada kesempatan ini, penulis ingin melakukan upaya peningkatan pembelajaran menulis argumentasi pada mata pelajaran bahasa Indonesia sebagai sarana pengembangan penalaran. Untuk mengembangkan penalaran, siswa dituntut untuk mampu menulis sebagai sarana mengungkapkan gagasan secara tertulis.

Untuk meningkatkan kemampuan menulis pada siswa sebagai sarana pengembangan penalaran, maka dipilihlah metode yang pembelajaran yang tepat. Untuk mencapai fungsi dan tujuan tersebut, maka salah satu metode/strategi pembelajaran yang ditawarkan di sini adalah strategi pramenulis cubing. Menurut Scarcella (via Refnaldi, 2002:28) menyatakan bahwa cubing berguna untuk penjelajahan sebuah topik secara cepat. Keistimewaaannya, cubing memungkinkan penulis menjajaki sebuah topik melalui multiple perspektif. Sebagai sarana pendukung proses belajar mengajar, materi yang akan menjadi pokok kajian disini adalah tentang karangan/tulisan argumentasi.

Penelitian tentang keterampilan menulis argumentasi ini diangkat karena di lapangan siswa kurang mampu mengarang ketika diberi tugas guru untuk menulis karangan. Pembelajaran menulis sudah dilakukan oleh guru dengan beberapa metode dan pendekatan. Akan tetapi, usaha yang dilakukan oleh guru belum menunjukkan hasil yang memuaskan bagi guru maupun siswa. Siswa belum merasakan suasana belajar yang menyenangkan, aktif, dan kreatif di dalam kelas.

Untuk mengadakan evaluasi guna melakukan pembenahan terhadap kualitas pembelajaran keterampilan menulis argumentasi, dapat dimulai dari pemilihan strategi pembelajaran yang tepat. Oleh karena itu, upaya tindakan ini akan mencoba meningkatkan kemampuan siswa pada pembelajaran keterampilan menulis argumentasi dengan strategi pramenulis cubing. Karena pada umumnya, pembelajar yang mempunyai nilai kompetensi tinggi, akan tinggi pula nilai keterampilan berbahasanya. Hal ini dapat dimengerti sebab tindak berbahasa tidak lain daripada mengoperasian kompetensi kebahasaan yang dimiliki. Oleh karena itu, baik tidaknya kompetensi pembelajar, pada umumnya akan mencerminkan keterampilan berbahasanya (Nurgiyantoro, 1995).

Penelitian ini secara umum bertujuan untuk meningkatkan kemampuan menulis argumentasi siswa kelas VIII SMP Negeri I Bambanglipuro Bantul Yogyakarta, baik secara proses maupun kualitasnya dengan strategi pramenulis cubing. Tujuan khusus berdasarkan pada rumusan masalah dalam penelitian ini, yakni menemukan strategi yang tepat untuk meningkatkan keterampilan menulis argumentasi siswa. Salah satu strategi yang diterapkan untuk meningkatkan kemampuan keterampilan menulis argumentasi siswa menjadi lebih baik adalah strategi pramenulis cubing.

\section{B. METODE PENELITIAN}

Prosedur dalam penelitian ini adalah penelitian tindakan kelas (PTK). Untuk melaksanakan PTK yang terarah dan teratur dalam prosesnya yang panjang dan kompleks, maka pelaksanaan penelitian dilakukan dengan siklus dan dilanjutkan dengan pengamatan, refleksi dan pelaporan Arikunto (2008). Siklus tersebut adalah pratindakan, siklus I, siklus II, dan seterusnya. Peneliti kemudian mempertajam judul atau objek penelitian, mengidentifikasi masalah penelitian, mereviu kepustakaan, menetapkan konsep dan tujuan penelitian. Pada saat di lapan- 
gan, peneliti melakukan bimbingan, tanyajawab, pengamatan, pencatatan dan meminta tugas siswa berupa tulisan argumentasi untuk sumber data. Peneliti melakukan kunjungan berkali-kali untuk melakukan aksi dan pengumpulan data.

a. Siklus pertama

Kegiatan yang dilakukan peneliti bersama guru pada siklus pertama adalah:

1) Perencanaan

Dalam tahap perencanaan penelitian meliputi; menyiapkan bahan ajar, membuat media, menyusun rencana pembelajaran (RPP), menyusun skenario pembelajaran, menyusun tugas-tugas menulis karangan argumentasi, menyusun lembar observasi, membuat rambu-rambu penilaian proses dan hasil belajar siswa.

2) Pelaksanaan

Kegiatan yang dilakukan pada tahap pelaksanaan adalah sebagai berikut.

a. Siswa memahami penjelasan guru tentang tujuan pembelajaran dan garis besar meteri yang akan dipelajari

b. Siswa menyimak materi tentang materi menulis argumentasi

c. Siswa menyimak dan memahami langkah-langkah strategi pramenulis cubing

d. Siswa membuat kerangka kubus untuk mengarang argumentasi

e. Siswa diberikan tugas menerapkan langkah-langkah strategi pramenulis cubing

f. Siswa bertanya jawab tentang penerapan langkah-langkah strategi cubing dengan teman dan gurunya

g. Siswa diberi tugas menulis karangan argumentasi berdasarkan data-data yang diperoleh melalui kegiatan penerapan strategi pramenulis cubing

h. Dengan dipandu guru, siswa mendiskusikan permasalahan-permasalahan yang dihadapi selama kegiatan menulis karangan argumentasi dengan strategi pramenulis cubing,

i. Peneliti mengobservasi kemudian memberikan kuis untuk mengetahui penguasaan konsep dan kemampuan menulis argumentasi siswa secara individual.
3) Pengamatan

Selama tahap pelaksanaan, peneliti melakukan hal-hal sebagai berikut.

a. Pengamatan terhadap penerapan strategi pramenulis cubing dalam menulis karangan argumentasi siswa dengan menggunakan lembar observasi yang telah disiapkan.

b. Membuat jurnal/catatan lapangan tentang keadaan di dalam kelas selama kegiatan belajar mengajar.

\section{4) Refleksi}

Kegiatan yang dilakukan pada tahap refleksi adalah sebagai berikut.

a. Mengumpulkan data hasil pengamatan baik dari lembar observasi maupun dari jurnal/catatan lapangan.

b. Menganalisis data hasil pengamatan.

c. Melakukan refleksi apakah tindakan yang telah dilakukan dapat meningkatkan proses pembelajaran menulis karangan argumentasi dan dapat meningkatkan hasil menulis karangan argumentasi siswa.

Dalam aktivitasnya, peneliti terlibat langsung dalam setiap tahapan bersama dosen Matakuliah Menulis. Tahapan tersebut dimulai dari perencanaan, pelaksanaan, pengamatan, dan refleksi. Apabila peneliti sudah mengetahui keberhasilan dan hambatan tindakan pada siklus pertama, maka peneliti dan kolabulator merancang tindakan siklus kedua. Kegiatan pada siklus kedua merupakan perbaikan pada siklus pertama disertai dengan pelbagai perbaikan dari kelemahan yang telah dilakukan.

Teknik pengumpulan data yang digunakan dalam penelitian ini berupa hasil pengamatan, wawancara, dan dokumentasi. Selain itu, data diperoleh dari tugas menulis esai mahasiswa kelas A JPBSI FBS UNY.

Analisis data dilakukan melalui tiga tahapan, yaitu mereduksi data, penyajian data, dan pengambilan kesimpulan. Reduksi data dilakukan dengan cara merekam, menafsirkan, dan menyeleksi (mengategorisasi) data penelitian yang berkaitan dengan fokus masalah. Penyajian data yaitu memberikan gambaran yang mengarah pada pemerolehan jawaban atas masalah penelitian. Penyajian data dikelompokkan berdasarkan fokus penelitian. Pengambilan 
simpulan menggambarkan hasil penelitian secara menyeluruh tentang sesuatu yang diteliti secara apa adanya. Peneliti menginterpretasi data untuk menghasilkan temuan.

Data penelitian dianalisis secara kualitatif. Keabsahan data dilakukan dengan trianggulasi (pengamatan, wawancara, dan dokumentasi). Agar tercapai reliabilitas data dilakukan diskusi antar peneliti, antar dosen (intraratter), dan dengan dosen yang terlibat. Validitas data diperoleh pada saat perencanaan, proses, dan hasil evaluasi.

\section{b. Siklus kedua}

Tahap kedua dilakukan tahapan-tahapan seperti pada siklus pertama, tetapi didahului dengan rencana ulang berdasarkan hasil-hasil yang diperoleh pada siklus pertama. Hal ini bertujuan agar diketahui kelemahan-kelemahan yang terjadi pada siklus pertama dan akan dilaksanakan lebih baik pada siklus ke dua. Direncanakan dalam penelitian ini dilaksanakan dua siklus. Akan tetapi, jika pelaksanaan di siklus kedua belum menunjukkan peningkatan proses maupun hasil pengajaran menulis, maka tim peneliti sepakat melanjutkan ke siklus ke tiga, keempat dst.

\section{PEMBahasan}

1. Hasil Prasurvei

Kegiatan prasurvei dilakukan pada Kamis, 10 April 2008 pukul 09.00 s.d. 11.40. Objek yang di survei adalah siswa kelas VIII $\mathrm{C}$ mata pelajaran Bahasa Indonesia. Survei ini dilakukan oleh seorang observer (dosen) untuk melihat proses pembelajaran menulis argumentasi. Hasil survai dicatat dan didiskusikan dengan guru pengampu untuk dilakukan langkah selanjutnya.

Setelah survei dilakukan oleh obsever, diperoleh hasil bahwa siswa kurang respon terhadap pembelajaran menulis argumentasi. Ketika guru memberikan tugas menulis, siswa mengaku kesulitan dan kurang tertarik. Saat pembelajaran menulis pun, mereka belum mampu menuangkan ide dan gagasannya dalam tulisan dengan baik. Proses pembelajaran dan diskusi terhadap kegiatan menulis belum semangat. Terlihat tidak lebih dari 7 siswa di kelas yang menunjukkan minat dan respon terhadap pembelajaran menulis. Selebihnya $( \pm$
28) siswa kurang respon dan antusias terhadap pembelajaran menulis argumentasi.

\section{Hasil Siklus Ke-1 \\ a. Perencanaan}

Sebelum siklus I dilaksanakan tim peneliti berdiskusi untuk menyamakan persepsi tentang penerapan startegi pramenulis cubing dalam pembelajaran. Diskusi ini dilakukan pada tanggal 17 April 2008 di ruang guru SMP Negeri I Bambanglipuro Bantul Yogyakarta. Langkah pertama yang dilaksanakan yaitu mendiskusikan secara detail tentang langkah-langkah strategi pramenulis cubing dan penerapannya dalam setiap tahapan.

Tahap satu menggambarkan (describe), yaitu mendeskripsikan subjek yang dapat berupa orang, abjek, proses atau ide. Misalnya "Harga Beras Petani". Harga beras petani rendah karena pemerintah meningkatkan impor beras. Tahap dua, membandingkan (Compare) misalnya dengan apa, harga beras yang tinggi atau rendah itu dibandingkan. Tahap ketiga, asosiasi/menghubungkan (associate) menggali pengetahuan penulis untuk mengungkapakan subjek/judul karangan. Tahap keempat, menganalisa/mengevaluasi (analize), yaitu menganalisis atau mengevaluasi kembali penyebab, masalah, penyelesaian terhadap subjek kajian. Tahap kelima, penerapan (apply) artinya dengan cara apa saja dapat dilakukan dan digunakan. Tahap Keenam argumen (argue) mengemukakan alasan-alasan terhadap subjek kajian. Setelah keenam tahap ini dilakukan siswa kemudian diminta untuk membacakan hasilnya ke depan dan siswa yang lain akan memberikan masukan dan tanggapan. Hal tersebut bertujuan agar terjadi diskusi dan kesepahaman antar siswa terhadap tulisannya.

Tim peneliti selanjutnya membahas tentang jadwal pelaksanaan tindakan, bahan materi tentang strategi pramenulis cubing, tema karangan, instrumen observasi dan instrumen penilaian pada tindakan. Selain itu, sebelum tindakan dilakukan tim peneliti sepakat mengadakan pretes menulis argumentasi pada siswa kelas VIII C SMP Bambanglipuro Bantul Yogykakarta. Pre-tes dilaksanakan pada hari Kamis tanggal 24 April 2008. Hasil pre-tes tersebut untuk mengetahui kemampuan menulis argumentasi 
siswa dan sebagai dasar pelaksanaan tindakan pada siklus pertama.

\section{b. Pelaksanaan Tindakan}

Implementasi tindakan pada siklus pertama dilakukan dua kali tatap muka yaitu Selasa, 29 April 2008 dan Selasa, 6 Mei 2008. Pelaksanaan pada siklus I (pertemuan pertama) dimulai pada pukul 10.00-11.45 WIB. Tindakan yang dilakukan guru saat pembelajaran ialah menjelaskan dengan rinci tentang pengertian, tujuan, manfaat, dan langkah-langkah strategi pramenulis cubing. Guru kemudian memberikan kesempatan kepada siswa untuk berdiskusi dan bertanya jawab tentang strategi pramenulis cubing. Saat berdiskusi guru mencoba untuk meyakinkan tingkat pemahaman dan penguasaan siswa terhadap materi pembelajaran. Siswa (Chanifatul Ummah) diminta untuk maju menjelaskan dan menuliskan di papan tulis tentang langkah pertama strategi cubing. Langkah kedua ditulis dan dijelaskan oleh Dedi Setiawan. Langkah ketiga oleh Dwi Astuti. Langkah keempat oleh Eko Wahyudi. Langkah Kelima oleh Eriyani, dan langkah keenam oleh Feri Budi. Tujuan guru meminta siswa maju menulis dan menjelaskan tentang strategi pramenulis cubing agar diperoleh keseragaman pemahaman tentang tahapan-tahapan dalam strategi tersebut. Perbedaan pemahaman/persepsi siswa langsung dikoreksi oleh guru, observer, dan siswa secara demokratis.

Pembelajaran pada siklus I berjalan dengan lancar. Siswa terlihat serius dan antusias saat penugasan dan diskusi. Mereka mengikuti dengan lancar, tetapi waktu yang telah direncanakan dalam siklus pertama belum tepat. Waktu untuk penugasan dan diskusi belum maksimal sehingga perlu adanya koreksi untuk pelaksanaan siklus berikutnya.

Observasi dilakukan oleh kolaborator saat pembelajaran berlangsung. Pengamatan dilakukan secara langsung yang tertulis dalam instrumen catatan lapangan, lembar observasi dan kamera.

\section{c. Refleksi siklus 1}

Refleksi dilakukan pada tanggal 6 Mei 2008 di ruang guru SMP Negeri I Bambanglipuro Bantul Yogyakarta. Refleksi pertama dilakukan setelah tim peneliti melaksanakan siklus I dan proses observasi saat pembelajaran. Refleksi dilaksanakan oleh dosen (observer) dan guru.

Berdasarkan hasil pengamatan proses dan hasil produk pada siklus pertama dilaporkan sebagai berikut.

(1) Siswa mulai terjadi perubahan sikap dalam pembelajaran menulis argumentasi. Mereka lebih semangat untuk mengembangkan dan mengungkapkan gagasan-gagasannya saat pembelajaran.

(2) Siswa mengalami peningkatan kemampuan menulis argumentasi, yang pada awalnya mereka belum mempunyai keterampilan menulis sampai akhirnya mampu menuangkan gagasannya saat menulis argumentasi berdasarkan argumennya masing-masing.

(3) Siswa mampu mendeskripsikan subjek yang dapat berupa orang, objek, proses atau ide sesuai dengan topik yang berikan oleh guru. Topik menulis argumentasi pada siklus pertama ialah "Kebersihan Lingkungan". Siswa juga mampu membandingkan, menganalisis, menerapkan, dan memberikan argumen terhadap topik ketika menulis argumentasi.

Kekurangan dan hambatan yang ditemukan saat proses refleksi siklus pertama adalah sebagai berikut.

(1) Siswa masih ragu dalam mendeskripsikan dan menuliskan argumen terhadap topik menulis. Hal tersebut terlihat pada siklus I, deskripsi terhadap topik menulis argumentasi belum berkembang. Deskripsi masih sedikit dan belum runtut.

(2) Beberapa siswa masih bingung membedakan tahap compare dengan asosiate terbukti ada siswa yang bertanya tentang hal tersebut.

(3) Sebagian siswa putra yang duduk di belakang masih ada yang bergurau dengan teman sebangkunya.

(4) Siswa saat menuangkan argumen/ide belum mengembangkan pengetahuannya. Hal ini terlihat, kerangka tulisan yang terekam dalam hasil karangan dengan strategi pramenulis cubing masih sederhana (pengembangan ide belum luas). 
(5) Waktu yang digunakan untuk diskusi dan penugasan menulis argumentasi belum tepat. Siswa kekurangan waktu saat mengerjakan tugas dan proses diskusi pun belum maksimal.

Hambatan-hambatan tersebut di atas, tentunya sangat penting untuk diperbaiki pada siklus kedua. Ada tiga hal penting yang perlu dilakukan guru dan observer pada siklus berikutnya, yaitu (1) guru harus menentukan topik menulis sebelum pembelajaran dan siswa diwajibkan untuk mempelajarinya dari sumber lain. (2) Perbaikan alokasi waktu dalam pembelajaran (3) Mematangkan kesepahaman langkah strategi pramenulis cubing, terutama pada compare, asosiate dan argumen.

\section{Laporan Siklus Ke-2 \\ a. Perencanaan}

Perencanaan siklus kedua dilaksanakan pada Senin tanggal 3 Juni 2008 tepatnya setelah siklus pertama dilakukan. Tim peneliti sepakat untuk memperbaiki alokasi waktu proses pembelajaran pada RP (rencana pembelajaran) dan pemilihan topik menulis yang tepat. Selain itu, disepakati pula bahwa sebelum proses pembelajaran pada siklus kedua, tim akan bertemu kembali untuk mengecek instrumen, terutama RP, materi, sumber belajar, dan penertipan siswa ketika proses pembelajaran. Pematangan tersebut dilaksanakan tim pada tanggal 5 Juni 2008 pukul 07.00 WIB sebelum pembelajaran dimulai.

\section{b. Pelaksanaan Tindakan}

Tindakan pada siklus kedua dilakukan dua kali tatap muka yaitu pada hari Kamis, 5 Juni 2008 dan Kamis, 12 Juni 2008 pukul 10,00 WIB. Pelaksanaan pembelajaran dilaksanakan setelah guru memberikan penjelasan tentang pentingnya penerapan strategi pramenulis cubing dalam kegiatan menulis argumentasi. Siswa diminta untuk melaksanakan proses pembelajaran dengan serius dan memanfaatkan alokasi waktu dengan efektif.

Guru kemudian mulai menyampaikan materi tentang strategi pramenulis cubing terutama pada tahap compare, asociate dan argumen. Karena pada siklus pertama siswa masih lemah dalam membandingkan, mengaso- siasikan dan menyampaikan argumennya pada karangan, maka guru mendiskusikan kembali secara detail dengan siswa. Untuk memperoleh kesepahaman yang sama, guru meminta siswa (Nurul Hidayah) untuk menjelaskan kembali tentang langkah-langkah strategi Cubing. Setelah mendapatkan kesepahaman yang sama guru kemudian memberikan kesempatan pada siswa untuk bertanya. Waktu yang digunakan untuk pematangan strategi Cubing adalah 30 menit.

Guru kemudian mulai menuliskan sebuah tema "Cara Belajar Yang Efektif". Seluruh siwa melakukan setiap tahapan pramenulis cubing dengan pembagian waktu yang sudah ditentukan sebelumnya. Waktu yang diperlukan pada setiap tahap adalah 10 menit dan ditambah 10 menit diakhir untuk mengecek kembali.

Siswa mengerjakan secara individu (sendiri) dalam setiap tahap. Hal tersebut bertujuan untuk menggali kemampuan dan pemahaman siswa berdasarkan pengalaman yang dimilikinya. Hasil kerja siswa pun sangat beragam dan sangat bergantung pada hasil pengalamannya masing-masing (tertuang dalam tahap pertama describe).

Pada siklus ke-2 ini, siswa lebih serius dan bersemangat. siswa juga sudah mampu mengatur waktu yang diperlukan dalam setiap tahap strategi cubing. Topik menulis argumentasi yang dipilih adalah yang berkaitan dengan pengalaman yang sering dialami langsung oleh siswa, yaitu "Cara Belajar yang Efektif". Hal tersebut menjadikan siswa menjadi lebih serius, menguasai, dan bersemangat untuk menulis argumentasi. Siswa berlomba-lomba untuk menuangkan gagasan dan ide yang dimilikinya, agar berbeda dengan ide/gagasan dengan siswa yang lain.

Pengamatan dilakukan oleh guru pengampu dan dosen (observer). Instrumen yang digunakan saat pengamatan yaitu lembar catatan lapangan, lembar observasi, dan kamera.

\section{c. Refleksi}

Pelaksanaan refleksi pada hari Kamis tanggal 12 Juni 2008 pukul 13.00 pada setelah siklus kedua di ruang guru SMP N Bambanglipuro Bantul. Refleksi dilakukan berdua yaitu guru pengajar dan dosen (observer sekaligus kolaborator). Keberhasilan dalam siklus kedua 
dapat dilihat sebagai berikut.

(1) Terjadi peningkatan kemampuan menulis argumentasi siswa. Hal ini dapat dilihat dari perbedaan skor rata-rata pretes, siklus I dan siklus II. Peningkatan skor ini akan dibahas dalam hasil penelitian.

(2) Siswa lebih serius, semangat dan senang menulis argumentasi. Hal tersebut terlihat pada hasil tahap pertama sampai pada tahap keenam. Pada langkah asosiasi dan membandingkan siswa sudah dapat dengan lancar mengerjakan sesuai dengan konsep awal. Hal tersebut dapat dilihat pada hasil karangan argumentasi siswa.

(3) Siswa memiliki pengalaman menerapkan metode pramenulis cubing sebagai bekal ketika akan mengarang. Mereka juga dapat mengatur waktu ketika menulis dan mengerjakan tugas saat pembelajaran.

(4) Siswa akan lebih kreatif mengungkapkan pengalaman yang dimilikinya dalam karangan argumentasi melalui strategi pramenulis cubing. Selain itu, siswa dituntut lebih tekun lagi belajar karena tuntutan penerapan strategi cubing adalah mempunyai pengalaman dan argumen-argumen yang baik untuk ditulis dalam sebuah karangan.

Pelaksanaan siklus kedua berjalan lancar. Hambatan-hambatan yang dialami siswa, tidaklah bersifat krusial. Sehingga dosen maupun kolaborator memutuskan penerapan strategi pramenulis cubing sudah terlaksana dengan baik.

\section{Pembahasan Hasil Penelitian}

Hasil penelitian ini akan dibahas sesuai dengan rumusan masalah, yaitu peningkatan kemampuan menulis argumentasi dengan metode pramenulis cubing dalam mata pelajaran bahasa Indonesia. Berikut ini deskripsi kondisi kemajuan yang diperoleh dalam siklus pertama dan kedua. Selama tindakan dalam dua siklus terdapat perkembangan dalam tiga aspek, yaitu perapan strategi cubing dalam mata pelajaran bahasa Indonesia, Kemampuan menulis argumentasi siswa, pengungkapan argumen dalam karangan (mengungkapkan pendapat/argumen siswa) dan suasana proses pembelajaran.

\section{a. Peningkatan Kemampuan Menulis Ar- gumentasi}

Peningkatan kemampuan menulis argumentasi diperoleh dari peningkatan skor rerata pre-test ke skor rerata siklus I. Peningkatan diperoleh pula dari skor rerata sklus I ke skor reratara siklus II. Penigkatan dari awal sampai akhir siklus dapat kita lihat dalam paparan berikut ini.

1) Peningkatan Skor Rerata Pretest ke Akhir Siklus I

Hasil skor pretest diperoleh skor rerata $(63,18)$ dan skor rerata skor siklus I adalah $(67,67)$. Peningkatan skor rerata dari pre-tes ke siklus I ialah $(3,44)$. Oleh karena itu, dapat disimpulkan diperoleh peningkatan kemampuan menulis argumentasi dari pre-test atau pratindakan ke siklus I (tindakan).

Berdasarkan hasil penelitian siklus I menunjukkkan bahwa strategi cubing dapat meningkatkan kemampuan siswa dalam menulis argumentasi. Hal ini dapat kita perhatikan perbedaan skor rerata pre-tes dengan skor rerata siklus I yang mengalami peningkatan $(3,44)$. Maka terjadi peningkatan kemampuan menulis argumentasi dengan strategi pramenulis cubing setelah menerapkan strategi tersebut.

Peningkatan kemampuan siswa juga terlihat dalam penilaian proses pembelajaran dengan strategi cubing. Pada siswa terlihat respon positif selama proses belajar mengajar berlangsung. Siswa melaksanakan tugas menulis argumentasi, berperan aktif, berdiskusi dengan teman maupun dosen, dan berani presentasi ke depan mengemukakan argumen dan pendapatnya yang ditulisnya. Aktivitas-aktivitas siswa tersebut tercermin dalam setiap tindakan yang telah dilakukan.

2) Peningkatan Skor Rerata Pretest ke Akhir Siklus II

Peningkatan skor kemampuan menulis argumentasi pada akhir siklus II dapat diperoleh dari perbedaan skor rerata pretest $(63,18)$ dengan skor rata-rata menulis argumentasi pada akhir siklus II $(73,63)$. Peningkatan skor rerata menulis argumentasi pada siklus ke II secara keseluruhan $(10,45)$. Peningkatan skor rerata ini sangat signifikan karena hasil skor siklus II sudah di atas batas rata-rata $(>70,00)$ yang ditentukan oleh peneliti. 
Tabel 1. Deskripsi Kondisi dan Kemajuan Tindakan Penelitian

\begin{tabular}{|c|c|c|c|}
\hline \multirow{2}{*}{ Aspek } & \multicolumn{3}{|c|}{ Deskripsi Kemajuan } \\
\hline & Prasurvei & Siklus I & $\begin{array}{l}\text { Siklus II } \\
\end{array}$ \\
\hline $\begin{array}{l}\text { Penerapan } \\
\text { strategi } \\
\text { pramenulis } \\
\text { cubing }\end{array}$ & $\begin{array}{l}\text { Belum } \\
\text { diterapkan }\end{array}$ & $\begin{array}{l}\text { Sudah diterapkan. Siswa ketika } \\
\text { menerapkan strategi cubing } \\
\text { masih ragu-ragu dan } \\
\text { penggunaan waktu belum } \\
\text { digunakan dengan baik. Pada } \\
\text { langkah asosiasi dan } \\
\text { membandingkan masih bingung. }\end{array}$ & $\begin{array}{l}\text { Diterapakan dengan persiapan lebih } \\
\text { optimal. Siswa semakin yakin, } \\
\text { berkembang, dan pembelajaran } \\
\text { diarahkan pada peningkatan } \\
\text { kemampuan menulis argumentasi. } \\
\text { Waktu yang digunakan sudah diatur } \\
\text { dengan baik dalam RPP. }\end{array}$ \\
\hline $\begin{array}{l}\text { Kemampuan } \\
\text { menulis } \\
\text { Argumentasi }\end{array}$ & $\begin{array}{l}\text { Siswa masih } \\
\text { rendah dalam } \\
\text { kemampuan } \\
\text { menulis } \\
\text { argumentasi }\end{array}$ & $\begin{array}{l}\text { Hanya diperoleh peningkatan } \\
\text { kemampuan menulis, tapi ide, } \\
\text { asosiasi, dan argumen masih } \\
\text { lemah. }\end{array}$ & $\begin{array}{l}\text { Kemampuan menulis argumentasi } \\
\text { sudah meningkat. Siswa sudah } \\
\text { melakukan menulis argumentasi dan } \\
\text { menuangkannya melalui strategi } \\
\text { pramenulis cubing dengan baik. Hal } \\
\text { tersebut dapat dilihat pada hasil skor } \\
\text { rata-rata tabel } 2 \text {. }\end{array}$ \\
\hline $\begin{array}{l}\text { Kondisi proses } \\
\text { pembelajaran }\end{array}$ & $\begin{array}{l}\text { Motivasi } \\
\text { menulis } \\
\text { rendah dan } \\
\text { pembelajaran } \\
\text { kurang } \\
\text { kondusif }\end{array}$ & $\begin{array}{l}\text { Pembelajaran berjalan dengan } \\
\text { baik, tetapi siswa belum } \\
\text { mempunyai pendirian ketika } \\
\text { mengerjakan tugas. Pengalaman } \\
\text { yang dimiliki masih kurang } \\
\text { fokus pada topik karangan. } \\
\text { Siswa putra yang duduk di } \\
\text { belakang masih bergurau dengan } \\
\text { teman sebangkunya. }\end{array}$ & $\begin{array}{l}\text { Siswa terlihat serius, antusias dan } \\
\text { berpendirian. Tugas mandiri } \\
\text { diselesaikan dengan baik. } \\
\text { Pengalaman/pengetahuan siswa } \\
\text { bertambah baik karena guru sudah } \\
\text { memilih topik menulis yang } \\
\text { mendukung pembelajaran. Siswa } \\
\text { sudah siap pada topik karangan yang } \\
\text { diberikan guru. }\end{array}$ \\
\hline
\end{tabular}

Strategi pramenulis cubing ternyata mampu meningkatkan kemampuam siswa dalam menulis argumentasi. Hasil diskusi tim peneliti ternyata strategi cubing dapat meningkatkan kemampuan menulis argumentasi. Hal tesebut dapat dikaji pada pemaparan argumentasi pada langkah ke 6 berikut ini. Subjek penelitian berjumlah 34 siswa, sedangkan dua siswa tidak mengikuti ujian akhir karena sakit. Hasil evaluasi siklus II (akhir) nilai yang diperoleh siswa antara 60 s.d 70 sejumlah 12 siswa, nilai 71 s.d 80 sejumlah 19 siswa, dan nilai yang di atas 81 sejumlah 1 siswa dan dua siswa tidak ikut pos-tes.

\section{b. Kemampuan Mengungkapkan Ide dalam Tulisan}

Kemampuan siswa dalam menulis argumentasi di akhir siklus ke dua sudah baik. Hal tersebut tercermin dalam hasil pramenulis strategi cubing yang disusun sangat variatif dan berkembang. Artinya pemetaan kerangka tulisan, gagasan dan argumentasi yang disusun tidak monoton, tetapi siswa sudah mampu mengaitkan pengalaman ataupun pengetahuan sebelumnya untuk mengorganisasi ide dan mengembangkannya. Selain itu, ide-ide yang muncul juga sudah mengenai sasaran sesuai dengan topik tulisan yang ditentukan.

Judul tulisan sengaja diambil sesuai dengan pengalaman siswa. Hal ini berdasarkan kesepakatan antara guru dan tim peneliti. Tujuan pemilihan topik tersebut sebagai bahan pembelajaran siswa agar mampu menulis argumentasi sekaligus menerapkan strategi pramenulis cubing.

Berdasarkan Tabel 2, siswa menyatakan bahawa guru menjelaskan dengan jelas, variatif dan tidak membosankan masing-masing $69,7 \%$. Suasana kelas menyenangkan dan tidak menjenuhkan sebesar $63,6 \%$, sedangakan siswa termotivasi dan menyenangi pembelajaran menulis argumentasi $69,7 \%$.

Harapan siswa agar guru mempertahankan teknik mengajarnya sebesar $81,8 \%$. Siswa memperoleh pengetahuan/hal baru saat proses pembelajaran sebanyak $69,7 \%$, sedangkan siswa yang menyatakan pembelajran menulis argumentasi sulit dipahami hanya sebesar $6,06 \%$. siswa yang menjawab pembelajaran berlang- 
Tabel 2. Hasil Refleksi Siswa Terhadap Proses Pembelajaran

Jumlah Siswa: 34

Siswa yang Aktif: 33

\begin{tabular}{|c|c|c|c|c|}
\hline No & Respon Siswa & Proses Pembelajaran Menulis Argumentasi & Jmlh & Persentase \\
\hline \multirow[t]{13}{*}{1.} & Hasil Angket & Alasan Senang Mengikuti Pembelajaran Menulis & & \\
\hline & Respon Siswa & Argumentasi & & \\
\hline & & a. Guru menerangkan dengan jelas & 23 & $69,7 \%$ \\
\hline & & b. Banyak tugas/ PR & 7 & $21,2 \%$ \\
\hline & & c. Guru interaktif dan menyenangkan & 16 & $48,5 \%$ \\
\hline & & d. Guru tidak membosankan \& variatif & 23 & $69,7 \%$ \\
\hline & & e. Siswa menjadi aktif & 15 & $45,5 \%$ \\
\hline & & f. Ada diskusi kelompok & 3 & $9,09 \%$ \\
\hline & & g. Banyak kesempatan diskusi kelompok & 0 & $0 \%$ \\
\hline & & h. Media yang digunakan menarik & 12 & $36,4 \%$ \\
\hline & & i. Saya mendapatkan contoh yang menarik & 17 & $51,5 \%$ \\
\hline & & j. Suasana kelas menyenangkan & 21 & $63,6 \%$ \\
\hline & & $\mathrm{k}$. Saya menjadi termotivasi menulis & 23 & $69,7 \%$ \\
\hline \multirow[t]{11}{*}{2.} & Pendapat & Pendapat dan Harapan dalam Pembelajaran & & \\
\hline & Terhadap & a. Cara mengajar dipertahankan & 27 & $81,8 \%$ \\
\hline & Pembelajaran & b. Banyak hal baru yang menyenangkan & 23 & $69,7 \%$ \\
\hline & & c. Pembelajaran monoton & 0 & $0 \%$ \\
\hline & & d. Waktu pembelajaran terasa cepat & 12 & $36,4 \%$ \\
\hline & & e. Waktu pembelajaran terasa panjang & 3 & $9,09 \%$ \\
\hline & & f. Pembelajaran terasa mudah dipahami & 17 & $51,5 \%$ \\
\hline & & g. Pembelajaran terasa sulit dipahami & 2 & $6,06 \%$ \\
\hline & & h. Metode mempermudah saya belajar & 16 & $48,5 \%$ \\
\hline & & i. Saya suka jika guru tidak hadir & 7 & $21,2 \%$ \\
\hline & & j. Saya sedih jika guru tidak hadir & 9 & $27,3 \%$ \\
\hline \multirow[t]{4}{*}{3.} & $\begin{array}{l}\text { Pendapat Ketika } \\
\text { Menulis }\end{array}$ & $\begin{array}{l}\text { Pendapat ketika Proses Menulis Argumentasi } \\
\text { dengan strategi cubing }\end{array}$ & & \\
\hline & Argumentasi & a. Menyenangkan & 29 & $87,8 \%$ \\
\hline & & b. Tidak menyenangkan & 0 & $0 \%$ \\
\hline & & c. Biasa saja & 2 & $6,06 \%$ \\
\hline \multirow[t]{4}{*}{4.} & Kebebasan Saat & Perasaan Senang Menulis Argumentasi & & \\
\hline & Pembelajaran & a. Ya & 30 & $90,9 \%$ \\
\hline & & B. Tidak & 0 & $0 \%$ \\
\hline & & c. Tidak tahu & 3 & $9.09 \%$ \\
\hline 5. & $\begin{array}{l}\text { Penerapan } \\
\text { Metode }\end{array}$ & Strategi sangat membantu dalam proses pembelajaran & 31 & $93,9 \%$ \\
\hline
\end{tabular}

sung monoton adalah $0 \%$. Hal ini menunjukkan bahwa proses menulis argumentasi dengan strategi cubing menarik perhatian siswa.

Dengan melihat hasil prosentase tabel di atas siswa sangat terbantu dengan metode pembelajaran. $87,8 \%$ siswa menyatakan senang ketika proses menulis argumentasi dengan strategi cubing. Sebanyak 6,06\% siswa menjawab biasa saja ketika menulis argumentasi. Bahkan 93,9 \% menyatakan strategi cubinga sangat membantu dalam proses pembelajaran menulis argumentasi. Maka dari hasil tersebut dapat disimpulkan bahwa secara proses strategi cubing sangat membantu siswa ataupun guru, sehingga pelaksanaan pembelajaran menulis argumemtasi berjalan dengan kondusif.

\section{SIMPULAN}

Berdasarkan kegiatan penelitian dan pembahasan yang telah dilakukan, dapat ditarik simpulan sebagai berikut.

1. Penerapan Strategi pramenulis cubing dalam pembelajaran menulis argumentasi di SMP Negeri I Bambanglipuro Bantul Yogayakarta dapat membuat kemampuan menulis siswa menjadi lebih baik.

2. Pembelajaran menulis argumentasi yang dilakukan dengan strategi pramenulis cubing berdampak siswa semakin aktif, interaktif, dan antusias terhadap gurunya maupun dengan siswa lain.

3. Kualitas dan kuantitas keterampilan menulis argumentasi siswa juga meningkat menjadi lebih baik. 
4. Pembelajaran Bahasa Indonesia, khususnya keterampilan menulis tidak lagi menjadi beban dan sebaliknya akan menjadi kegiatan yang menyenangkan untuk siswa.

Saran-saran yang dapat disampaikan dari hasil penelitian ini adalah sebagai berikut. Penelitian dengan penerapan strategi pramenulis cubing sangat bermanfaat sebagai media meningkatkan kemampuan menulis argumentasi siswa. Oleh karena itu, sebaiknya penelitian ini tidak berhenti, tetapi dapat diterapkan guru dalam setiap pembelajaran menulis argumentasi di sekolah. Kegiatan ini sangat baik jika dilakukan dengan kerjasama antarintansi sebagai bagian pengembangan guru dan dosen untuk memperbaiki kualitas pembelajaran menulis.

\section{DAFTAR PUSTAKA}

Arikunto, Suharsimi. 2008. Penelitian Tindakan Kelas. Jakarta: Bumi Aksara.

Nurgiyantoro, Burhan. 2001. Penilaian dalam Penagajaran Bahasa dan Sastra. Edisi ketiga. Yogyakarta: BPFE.

Refnaldi. 2002. Brainstorming sebagai Strategi Penemuan dalam Proses Pembelajaran Menulis. Komposisi. Volume 3, No. 1 hlm 25-36.

Tarigan, Henry Guntur. 1994. Menulis sebagai Keterampilan Berbahasa. Bandung: Angkasa.

White, Fred D. 1986. The Writer's Art a Practical Rethoric and Handbook. New York: Wadsword Publishing Company. 